\title{
Primary small-cell cancer of the esophagus
}

Primary small-cell cancer of the esophagus is a rare tumor that disseminates early with a uniformly poor prognosis if untreated. Sixteen patients with malignant dysphagia referred to the Thoracic Surgical Unit, City Hospital, Edinburgh, within a 10-year period had a diagnosis of primary small-cell cancer of the esophagus. Seven patients underwent subtotal esophagectomy or esophagogastrectomy, either alone or with adjuvant chemotherapy or radiotherapy, with a mean survival of 20 months (standard deviation 35.4 months, range 2 weeks to 96 months). The remaining nine patients had disseminated disease when they were first seen and were treated symptomatically by intubation alone (1 patient), intubation and palliative chemotherapy or radiotherapy ( 3 patients), palliative chemotherapy ( 2 patients), palliative radiotherapy ( 1 patient), or no therapy ( 2 patients), with a mean survival of 4.8 months (standard deviation 2.6 months, range 2 to 9 months). Patients seen with this aggressive tumor should be assessed urgently for evidence of metastatic spread and then offered resection in combination with chemotherapy if they are otherwise fit for operation. This treatment regimen has given us one long-term survivor ( 96 months) who, we believe, is the only patient to have been cured of this condition. Patients seen with disseminated disease should have symptomatic treatment of the dysphagia combined with palliative chemotherapy. ( $J$ THORAC CARDIOVASC SURG 1995;109:284-88)

\author{
S. R. Craig, FRCS, ${ }^{a}$ F. A. Carey, MRCPath, ${ }^{b}$ W. S. Walker, FRCS, ${ }^{a}$ and \\ E. W. J. Cameron, FRCS, ${ }^{a}$ Edinburgh, Great Britain
}

$P_{r}$

rimary small-cell cancer of the esophagus, first reported by $\mathrm{McKeown}^{1}$ in 1952, is a rare tumor, similar to small-cell cancer of the ling, characterized by early dissemination and death if untreated. ${ }^{2}$ Esophageal small-cell carcinoma is identical morphologically to its more common bronchial counterpart, consisting of round to spindle-shaped cells with scanty cytoplasm, granular nuclei, inconspicuous nucleoli, and ultrastructural and immunohistochemical evidence of neuroendocrine differentiation. The cells may be argyrophil positive with neurosecretory granules seen on electron microscopy. ${ }^{3}$ Immunohistologically these cells are immunoreactive with low-molecular-weight cytokeratins and epithelial

From the Department of Thoracic Surgery, ${ }^{\text {a }}$ City Hospital, and the Department of Pathology, ${ }^{b}$ University of Edinburgh, Edinburgh, Great Britain.

Received for publication June 24, 1994.

Accepted for publication Sept. 9, 1994.

Address for reprints: S. R. Craig, FRCS, Department of Thoracic Surgery, City Hospital, Edinburgh, EH10 5SB, Great Britain.

Copyright (C) 1995 by Mosby-Year Book, Inc.

$0022-5223 / 95 \$ 3.00+0 \quad 12 / 1 / 60637$ membrane antigen, which is similar to the immunoreactivity of bronchogenic small-cell cancer. ${ }^{4} \mathrm{Neo}-$ plasms of the small-cell type have been recognized in a variety of extrapulmonary sites including, most frequently, the esophagus. ${ }^{5}$ The management of primary small-cell cancer of the esophagus remains controversial with groups reporting treatment based on operation alone, ${ }^{6}$ local radiotherapy, ${ }^{7}$ chemotherapy alone, ${ }^{3,8,9}$ or operation with adjuvant therapy. ${ }^{10}$ Overall survival remains poor at a mean of 5.1 months, with the best rate of survival in patients undergoing operation with adjuvant chemotherapy. ${ }^{2}$

This report describes the clinical and pathologic features of 16 patients seen at our thoracic surgical unit with primary small-cell cancer of the esophagus and outlines a management strategy based on the available literature, which at present stands at fewer than 200 cases reported worldwide.

\section{Patients and methods}

Patients with a diagnosis of small-cell cancer of the esophagus were identified from clinical and pathologic records from a 10 -year period. The clinical, radiographic, and pathologic findings were reviewed and all patients in 
Table I. Summary of patients who underwent operation for small-cell carcinoma of esophagus

\begin{tabular}{|c|c|c|c|c|c|c|}
\hline Patient & $\begin{array}{l}\text { Age } \\
(y r)\end{array}$ & Sex & Operation & Sunival & Recurrence & Adjuvant therapy \\
\hline 1 & 39 & $\mathrm{~F}$ & Subtotal esophagectomy & Alive at $96 \mathrm{mo}$ & None & Chemotherapy \\
\hline 2 & 57 & $\mathrm{~F}$ & Subtotal esophagectomy & Died at $12 \mathrm{mo}$ & $\begin{array}{l}\text { Pulmonary at } 4 \mathrm{mo} \\
\text { bone at } 9 \text { mo }\end{array}$ & $\begin{array}{l}\text { Palliative radiother- } \\
\text { apy for bone me- } \\
\text { tastases }\end{array}$ \\
\hline 3 & 63 & $\mathbf{M}$ & Esophagogastrectomy & Died at $34 \mathrm{mo}$ & $\begin{array}{l}\text { Anastomotic at } 24 \\
\text { mo }\end{array}$ & Laser therapy \\
\hline 4 & 64 & $\mathrm{~F}$ & $\begin{array}{l}\text { Esophagogastrectomy, } \\
\text { splenectomy, partial pan- } \\
\text { createctomy }\end{array}$ & Died at $5 \mathrm{wk}$ & $\begin{array}{l}\text { Rapid deteriora- } \\
\text { tion, no postmor- } \\
\text { tem study }\end{array}$ & None \\
\hline 5 & 62 & $\mathrm{~F}$ & Esophagogastrectomy & Alive at $6 \mathrm{mo}$ & None & $\begin{array}{l}\text { Radiotherapy to me- } \\
\text { diastinum }\end{array}$ \\
\hline 6 & 48 & F & Subtotal esophagectomy & Died at $2 \mathrm{wk}$ & $\mathrm{N} / \mathrm{A}$ & None \\
\hline 7 & 55 & F & Subtotal esophagectomy & Died at $3 \mathrm{mo}$ & N/A & None \\
\hline
\end{tabular}

Chemotherapy consisted of methotrexate, cyclophosphamide, etoposide.

whom esophageal invasion by a primary bronchial smallcell carcinoma could not be ruled out were excluded from the study. A total of 16 patients identified from the records were considered to have a primary esophageal small-cell carcinoma.

The records were examined and the presenting symptoms, method of tumor diagnosis, staging procedures done, therapy, pathologic findings, and clinical outcome recorded. Histologic sections were reviewed to confirm the diagnosis of small-cell carcinoma. Features of associated dysplasia/carcinoma in situ, Barrett's esophagus, mixed patterns of histologic differentiation, and lymph node metastases were specifically sought. Immunohistochemistry testing for epithelial and lymphoid markers was done when lymphoma had been included in the differential diagnosis.

\section{Results}

Sixteen patients with primary small-cell cancer of the esophagus were identified within a 10 -year period during which more than 600 esophagogastrectomies because of esophageal or proximal gastric cancer were done. There were 11 women and 6 men with an age range of 39 to 72 years (mean 60 years). Seven of these patients had been treated primarily by resection and nine had been given palliative treatment because of dissemination of the primary tumor at the time of presentation. All patients reported dysphagia and weight loss; in addition one had hematemesis and melena and two were hoarse because of vocal cord paralysis as a result of involvement of the left recurrent laryngeal nerve.

Surgical group. Seven patients had the primary small-cell cancer of the esophagus resected on the grounds that the preoperative work-up had excluded distant metastatic disease. A summary of the details of these patients is given in Table I. All patients had endoscopic and contrast examinations of the esoph- agus and no evidence of a bronchogenic small-cell primary tumor on bronchoscopy, chest radiograph, or thoracic computed tomographic (CT) scan. Liver ultrasonography was done before resection in all patients to exclude liver metastases. Calcium, phosphate, and alkaline phosphatase levels were measured in an attempt to exclude occult bone metastases. Any history of bone pain was investigated by radiograph and isotopic bone scan. Pulmonary function tests were done along with a full noninvasive assessment of cardiac function before thoracolaparotomy.

A preliminary laparotomy was done in all cases to exclude extranodal spread. Four patients underwent a subtotal esophagectomy, two an esophagogastrectomy, and one an esophagogastrectomy combined with splenectomy and partial pancreatectomy. After resection an esophagogastrostomy was fashioned with a circular stapler (ILS stapler, Ethicon Ltd., Edinburgh, United Kingdom) or interrupted silk sutures (Mersilk, Ethicon Ltd.). A barium contrast examination was done on postoperative day 5 to check the anastomosis. All patients were closely monitored in the outpatient department after discharge from the hospital.

All patients who underwent esophageal resection had histologically confirmed small-cell cancer of the esophagus (Table II). The surgical resection specimens showed mixed histologic types in four out of the seven cases. In three of these the appearances were of mixed squamous and small-cell carcinoma and one case showed mixed small-cell carcinoma and adenocarcinoma. Three of the seven resected specimens showed foci of squamous carcinoma in situ, and this change was extensive in one case. 
Table II. Pathologic findings in patients who underwent resection for primary esophageal smallcell cancer

\begin{tabular}{|c|c|c|c|}
\hline Patient & Histologic type & $\begin{array}{c}\text { Lymph node } \\
\text { status }\end{array}$ & $\begin{array}{c}\text { Resection } \\
\text { margins }\end{array}$ \\
\hline 1 & Small-cell carcinoma & $\begin{array}{c}\text { Metastases in two } \\
\text { lymph nodes }\end{array}$ & Clear \\
\hline 2 & $\begin{array}{l}\text { Small-cell carcinoma } \\
\text { and adenocarci- } \\
\text { noma }\end{array}$ & $\begin{array}{l}\text { Metastases in } \\
\text { multiple nodes }\end{array}$ & Clear \\
\hline 3 & Small-cell carcinoma & $\begin{array}{l}\text { Metastasis in sin- } \\
\text { gle lymph node }\end{array}$ & Clear \\
\hline 4 & Small-cell carcinoma & $\begin{array}{l}\text { Lymph nodes } \\
\text { normal }\end{array}$ & Clear \\
\hline 5 & $\begin{array}{l}\text { Small-cell carcinoma } \\
\text { and squamous } \\
\text { carcinoma }\end{array}$ & $\begin{array}{c}\text { Metastases in two } \\
\text { lymph nodes }\end{array}$ & Clear \\
\hline 6 & $\begin{array}{l}\text { Small-cell carcinoma } \\
\text { and squamous } \\
\text { carcinoma }\end{array}$ & $\begin{array}{l}\text { Metastases in } \\
\text { multiple nodes }\end{array}$ & Clear \\
\hline 7 & $\begin{array}{l}\text { Small-cell carcinoma } \\
\text { and squamous } \\
\text { carcinoma }\end{array}$ & $\begin{array}{l}\text { Metastases in } \\
\text { multiple nodes }\end{array}$ & Clear \\
\hline
\end{tabular}

Barrett's metaplasia was not detected in any of the specimens. In keeping with early dissemination all but one patient had evidence of local nodal metastases. The patient with no evidence of nodal metastatic disease did have microscopic invasion of the perigastric fat.

In the postoperative period chylothorax and respiratory failure developed in one patient who had had a subtotal esophagectomy, which required a prolonged period of ventilation and parenteral nutrition. Other perioperative complications included a chest infection (1 patient) and atrial fibrillation (1 patient). One patient died at 14 days (operative mortality rate $14 \%$ ) of a pulmonary embolus.

The patient with perigastric fat invasion died of rapid progression of the disease and was too frail to undergo any form of palliative therapy, as was another patient who died at 3 months. This patient, it is presumed, must have had undiagnosed metastatic disease at the time of presentation. The other four patients fared better with a mean survival of 37 months (standard deviation 41.1 months, range 6 to 96 months). Two patients are alive, one at 96 months who underwent adjuvant chemotherapy and one at 6 months with no evidence of recurrence who received mediastinal radiotherapy for lymphatic metastases. The chemotherapy consisted of four courses of methotrexate, cyclophosphamide, and etoposide. The other two patients died at 12 and 34 months, respectively. The patient who died at 12 months had pulmonary and then bone metastases that developed shortly after a prolonged in-patient hospital stay because of a chylothorax and respiratory failure, which necessitated a period of ventilator support. She received palliative radiotherapy to the symptomatic bone metastases.

The patient who died at 34 months had received no adjuvant therapy; however, he remained well until an anastomotic recurrence was diagnosed 24 months after operation despite initially clear resection margins. He received laser therapy to the anastomotic recurrence, which relieved dysphagia until his death 10 months later.

Palliative group. Nine patients were identified with disseminated disease at the time of presentation. Small-cell esophageal cancer was diagnosed by endoscopic biopsy in all cases. In the biopsy specimens the tumor consisted of sheets and nests of polygonal to spindle-shaped cells with a fine fibrovascular supporting network. Crush artifact was common. In two cases immunohistochemical staining for cytokeratin showed a characteristic paranuclear "dot" positivity. A further two cases showed foci of squamous differentiation. The overlying squamous epithelium showed dysplasia in three patients and features of carcinoma in situ in one.

Four patients had cervical lymphadenopathy that was subjected to biopsy and confirmed histologically to be metastatic small-cell cancer similar in appearance to the esophageal primary tumor. Two patients were hoarse because of involvement of the left recurrent laryngeal nerve associated with gross mediastinal lymphadenopathy on thoracic CT scan. One patient had liver metastases, one had extensive mediastinal and abdominal lymphadenopathy on CT scan, and one was too frail to contemplate esophageal resection. These patients with disseminated disease were treated by intubation alone (1 patient), intubation and palliative chemotherapy or radiotherapy ( 3 patients), palliative chemotherapy (2 patients), palliative radiotherapy (1 patient), or no therapy ( 2 patients). All patients were followed up in our outpatient department if no adjuvant therapy was given or by the oncologists or radiotherapists if they did receive adjuvant therapy.

The result of palliative treatment for the nine patients with disseminated disease at the time of presentation is summarized in Table III. Four patients required intubation of the malignant esophageal stricture because of severe dysphagia at the time of presentation. Six patients were treated with 


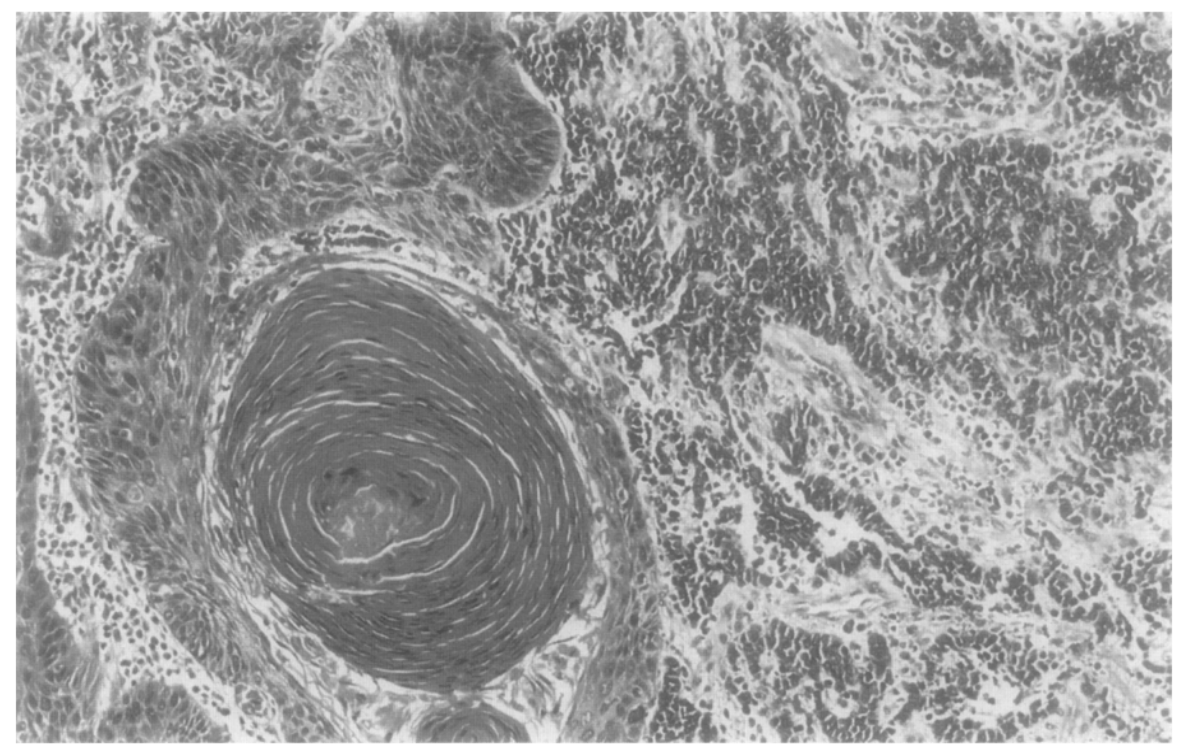

Fig. 1. Histologic section from surgical resection specimen showing mixed squamous cell and small-cell carcinoma (hematoxylin and eosin stain, original magnification $\times 100$ ).

Table III. Outcome of patients with disseminated disease at presentation

\begin{tabular}{ccclll}
\hline Patient & Age $(y r)$ & Sex & \multicolumn{1}{c}{ Reason for nonoperative status } & \multicolumn{1}{c}{ Palliation } & Outcome \\
\hline 1 & 64 & F & Cervical lymph nodes & None, rapid deterioration; frail & Died 2 mo \\
2 & 70 & F & Extensive mediastinal lymphadenopathy & None, rapid deterioration; frail & Died 2 mo \\
3 & 69 & M & Cervical lymph nodes & Chemotherapy & Died 7 mo \\
4 & 69 & F & Liver metastases & Palliative radiotherapy & Died 3 mo \\
5 & 55 & M & Extensive mediastinal lymphadenopathy & Intubation, radiotherapy, che- & Died 7 mo \\
& & & & motherapy & Died 3 mo \\
6 & 72 & M & Extensive para-aortic lymphadenopathy & Intubation & Died 7 mo \\
7 & 65 & M & Cervical lymph nodes & Intubation, chemotherapy & Died 3 mo \\
8 & 65 & F & Extensive mediastinal lymphadenopathy & Intubation & Died 9 mo \\
9 & 43 & F & Cervical lymph nodes & Chemotherapy & \\
\hline
\end{tabular}

Chemotherapy consisted of methotrexate, cyclophosphamide, etoposide.

palliative chemotherapy or radiotherapy with a mean survival of 6 months ( 1 standard error of mean). The three remaining patients who were unfit for any form of palliative therapy died at a mean time of 2 months after diagnosis.

\section{Discussion}

Over the past decade or so, small-cell carcinoma has become increasingly recognized as an unusual primary neoplasm of the esophagus. Small-cell carcinoma was initially thought to arise from argyrophilic Kulchitsky cells, which are found in both bronchial and esophageal mucosa. ${ }^{11}$ These cells have the ability to synthesize and store amines and to decarboxylate some amino acids: a feat that gave rise to the term APUD (amine precursor uptake, decarboxylation) cells. ${ }^{12}$ It would now appear that small-cell cancer is of endodermal origin derived from a pluripotential basal epithelial cell, similar to the proposed histogenesis of bronchogenic smallcell carcinoma, which explains the coexistence of small-cell, squamous, and glandular elements in the same lesion. ${ }^{13}$ Approximately $35 \%$ of primary smallcell cancers of the esophagus show this multiple differentiation. ${ }^{14}$ Our finding of a high incidence of histologic heterogenicity (Fig. 1) in surgically resected esophageal small-cell cancers (higher, in fact, than that of small-cell lung cancers) and of an association with squamous carcinoma in situ strongly supports this unified hypothesis.

Primary small-cell carcinoma of the esophagus has previously been labeled as an argyrophilic cell carcinoma (apudoma), ${ }^{6}$ as well as an oat cell, ${ }^{15}$ anaplastic, ${ }^{16}$ neuroendocrine, ${ }^{17}$ or small-cell epider- 
moid carcinoma, ${ }^{18}$ reflecting the previously uncertain histogenesis of this tumor.

Small-cell cancer of the esophagus shares immunohistochemical, histochemical, and histologic similarities with small-cell cancer of the bronchus, which suggests that they have a common derivation. ${ }^{14}$ They are both aggressive cancers characterized by early dissemination, which reduces the number of operable cancers at the time of diagnosis, though they do both have a significant response rate to appropriate chemotherapy. ${ }^{3,8,19}$ Those patients seen with esophageal small-cell cancer should be assessed with regards to ensuring that the tumor is a primary esophageal tumor and the extent of spread should be determined. Patients with disseminated disease should be offered palliative therapy associated with esophageal intubation if required. Although numbers are small it would appear that palliative chemotherapy offers longer survival than palliative radiotherapy. $2,7,8,9$

Patients with apparent operable disease should be offered resection in combination with adjuvant chemotherapy. It is to be expected that adjacent lymph nodes will be involved by metastatic deposits though this in itself does not rule out a prolonged period of survival, as this paper has shown. Other authors have suggested additional mediastinal and cranial irradiation if these glands are involved on the basis of existing treatment protocols for bronchogenic small-cell cancer. ${ }^{2}$

\section{REFERENCES}

1. McKeown F. Oat-cell carcinoma of the esophagus. $\mathbf{J}$ Pathol Bacteriol 1952;64:889-91.

2. McFadden DW, Rudnicki M, Talamini MA. Primary small cell carcinoma of the esophagus. Ann Thorac Surg 1989;47:477-80.

3. Tanabe G, Kajisa T, Shimazu $H$, et al. Effective chemotherapy for small cell cancer of the esophagus. Cancer 1987;60:2613-6.

4. Hoda SA, Hajdu SI. Small cell carcinoma of the esophagus: cytology and immunohistology in four cases. Acta Cytol 1992;36:113-20.

5. Richardson RL, Weiland LH. Undifferentiated small cell carcinomas in extrapulmonary sites. Semin Oncol 1982;9:484-96.

6. Tateishi R, Taniguchi T, Horai T, et al. Argyrophil cell carcinoma (apudoma) of the esophagus: a histopathologic entity. Virchows Arch A Pathol Anat Histopathol 1976;371:283-94.

7. Doherty MA, McIntyre M, Arnott SJ. Oat cell carcinoma of the esophagus: a report of six British patients with a review of the literature. Int J Radiat Oncol Biol Phys 1984;10:147-52.

8. Kelsen DP, Weston E, Kurtz R, et al. Small-cell carcinoma of the esophagus: treatment by chemotherapy alone. Cancer 1980;45:1558-61.

9. Eccles DM, Allan SG, Sang CTM, Cornbleet MA. Small cell carcinoma of the oesophagus and review of published cases. Thorax 1989;44:749-50.

10. Ge XZ. Surgical treatment of primary small cell carcinoma of the esophagus. Chung Hua Wai Ko Tsa Chih 1992;29:753-4, 797-8.

11. Tateishi R, Taniguchi H, Wada A, et al. Argyrophil cells and melanocytes in esophageal mucosa. Arch Pathol 1974;98:87-9.

12. Pearse AGE. The cytochemistry and ultrastructure of polypeptide hormone-producing cells of the APUD series and the embryonic, physiologic, and pathologic implications of the concept. J Histochem Cytochem 1969;17:303-13.

13. Ho KJ, Herrera GA, Jones JM, et al. Small cell carcinoma of the esophagus: evidence of a unified histogenesis. Hum Pathol 1984;15:460-8.

14. Tennvall J, Johansson L, Albertsson M. Small cell carcinoma of the oesophagus: a clinical and immunohistopathological review. Eur J Surg Oncol 1990;16: 109-15.

15. Sabanathan S, Graham GP, Salama FD. Primary oat cell carcinoma of the esophagus. Thorax 1986;41:318.

16. Matsusaka T, Watanabe H, Enjoji M. Anaplastic carcinoma of the esophagus. Cancer 1976;37:1352-8.

17. Paraf F, Serre I, Sarfati E, Celerier M, Brocheriou C. Neuroendocrine carcinoma of the esophagus. Ann Chir 1990;44:249-51.

18. Rosen Y, Moon S, Kim B. Small cell epidermoid carcinoma of the esophagus. Cancer 1975;36:1042-9.

19. Crompton G. Small cell lung cancer. BMJ 1990;300: 209-10. 